Clinica Chimica Acta, 106 (1980) 155-163

(C) Elsevier/North-Holland Biomedical Press

CCA 1467

\title{
A REVISED FLUOROMETRIC ASSAY FOR GAUCHER'S DISEASE USING CONDURITOL- $\beta$-EPOXIDE WITH LIVER AS THE SOURCE OF $\beta$-GLUCOSIDASE
}

\author{
LYDIA B. DANIELS ${ }^{a}$, ROBERT H. GLEW ${ }^{a},{ }^{*}$, NORMAN S. RADIN ${ }^{b}$ and \\ RANGA R. VUNNAM ${ }^{b}$ \\ a Department of Biochemistry, University of Pittsburgh School of Medicine, Pittsburgh, \\ PA 15261 (IJ.S.A.) and ${ }^{\mathrm{b}}$ Department of Psychiatry, Mental Health Research Institute, \\ University of Michigan, Ann Arbor, MI 48109 (U.S.A.)
}

(Received January 9th, 1980)

\section{Summary}

To date, enzymatic diagnosis of Gaucher's disease via a fluorometric assay procedure which utilizes 4-methylumbelliferyl- $\beta$-D-glucopyranoside as a substrate has not been possible when liver serves as the source of enzyme since currently employed fluorometric procedures cannot adequately differentiate between a broad-specificity $\beta$-glucosidase and lysosomal glucocerebrosidase activities in crude extracts of liver. Incorporation of conduritol- $\beta$-epoxide into the incubation medium for the fluorometric assay allows one to selectively measure the glucocerebrosidase activity present in a given liver extract. In five cases of Gaucher's disease this revised fluorometric procedure proved as effective as the assay procedure which utilizes authentic, radiolabeled glucocerebroside as the substrate in demonstrating a deficiency of glucocerebrosidase activity in liver.

\section{Introduction}

Gaucher's disease is an autosomal recessive, inborn error in the pathway of sphingoglycolipid metabolism. The disease is characterized by a marked deficiency of glucocerebrosidase activity in all tissues that have been examined, including liver, brain, spleen, fibroblasts and leukocytes [1]. The definitive diagnosis of Gaucher's disease rests on demonstrating a marked deficiency of glucocerebrosidase activity in tissue extracts using the radiolabeled natural substrate in an enzymatic assay [1]. This assay, however, is time-consuming and requires expensive, specialized equipment. A second and more convenient diag-

\footnotetext{
* To whom correspondence should be addressed.
} 
nostic assay is available which utilizes the non-physiologic fluorogenic substrate, 4-methylumbelliferyl- $\beta$-D-glucopyranoside (MUG). This fluorometric assay has been shown to give comparable results to those obtained using the authentic substrate-dependent assay when applied to specific tissues, most often leukocytes and fibroblasts [2].

The success of the fluorometric assay depends on how effectively it distinguishes between the two $\beta$-glucosidase activities which are present in most human tissues [3]. One $\beta$-glucosidase is relatively non-specific and cleaves a variety of glycosidic residues from the 4-methylumbelliferone moiety including $\beta$-D-glucose, $\beta$-D-galactose, $\alpha$-L-arabinose and $\beta$-D-fucose but it will not catalyze the hydrolysis of glucose from glucocerebroside. The second $\beta$-glucosidase is glucocerebrosidase and it catalyzes the cleavage of glucose from both glucocerebroside and MUG, but is unreactive toward other fluorogenic glycosides. For tissues that contain both $\beta$-glucosidases the ability of the fluorometric assay to detect a deficiency in glucocerebrosidase activity depends on adjusting the assay conditions such that the broad-specificity $\beta$-glucosidase is inhibited, thereby permitting an accurate determination of residual glucocerebrosidase activity $[2,4-8]$.

The ratio of non-specific $\beta$-glucosidase activity to glucocerebrosidase activity varies among tissues; there is essentially no broad-specificity $\beta$-glucosidase in fibroblasts, the ratio is about $30: 70$ in leukocytes, $7: 93$ in spleen, $17: 83$ in brain, and $83: 17$ in liver (see text). It follows that the tissues with the lowest levels of non-specific $\beta$-glucosidase activity, particularly fibroblasts, are the best sources of enzyme for the fluorometric assay. Other tissues can be used for diagnostic purposes as long as the assay conditions are adjusted such that nonspecific $\beta$-glucosidase activity is completely inhibited.

Recently, it was reported that the various fluorometric diagnostic assays give ambiguous results when liver is the source of the enzyme $[3,9]$. The problem with using a fluorometric assay is that liver is a particularly rich source of the non-specific $\beta$-glucosidase. In cases of Gaucher's disease where the non-specific $\beta$-glucosidase is elevated, a significant proportion of the activity measured will not be affected by the different inhibitors used in the various fluorometric assays [3]. The end result is that the fluorometric assay will often demonstrate normal or near-normal levels of residual MUG hydrolase activity in extracts of tissue from these patients but a profound deficiency of glucocerebrosidase activity when assayed using the authentic, radiolabeled substrate.

There will continue to be occasions when a liver biopsy will be submitted as the source of enzyme for diagnostic purposes in cases where there is a suspicion of a storage disorder. Such cases present frequently enough to have stimulated us to try to improve the conditions of the fluorometric assay so that it could be applied with confidence to liver. Conduritol- $\beta$-epoxide (CBE) is a potent, irreversible competitive inhibitor of various plant $\beta$-glucosidases and mammalian glucocerehrosidase [10-15]. We recently found that the activity of the non-specific $\beta$-glucosidase was unaffected by concentrations of $\mathrm{CBE}$ which completely inhibited glucocerebrosidase activity. In light of this information we wished to determine if CBE could be used to improve the effectiveness of the fluorometric assay for Gaucher's disease when liver served as the source of enzyme. 
The standard fluorometric assay measures glucocerebrosidase activity plus whatever residual non-specific $\beta$-glucosidase activity that is not inhibited by sodium taurocholate. The addition of CBE to the standard assay completely inhibits glucocerebrosidase activity, so that the resulting $\beta$-glucosidase measurement determines only the residual non-specific $\beta$-glucosidase activity. Therefore, if one subtracts the results of fluorometric assays performed in the presence of CBE from those obtained in the absence of $\mathrm{CBE}$, the difference will be a measure of relative $\beta$-glucocerebrosidase activity.

The present report describes an improved fluorometric assay for Gaucher's disease that includes CBE.

\section{Materials}

Pure sodium taurocholate from ICN Pharmaceuticals, Inc., 4-methylumbelliferyl- $\beta$-D-glucopyranoside from Koch-Light Laboratories, Ltd., $\left[1-{ }^{14} \mathrm{C}\right]$ stearic acid $(56.7 \mathrm{mCi} / \mathrm{mmol})$ from ICN Isotope and Nuclear Division of ICN Pharmaceuticals, Inc., Unisil (activated silicic acid, 200-325 mesh) from Clarkson Chemical Co., conduritol- $\beta$-epoxide was prepared according to Legler [11], and [ $N$-stearoyl $\left.{ }^{14} \mathrm{C}\right]$ glucocerebroside was prepared according to the method of Erickson and Radin [16] and was diluted with unlabeled glucocerebroside isolated from Gaucher spleen to a specific activity of $700 \mathrm{cpm} / \mathrm{nmole}$.

\section{Methods}

\section{Tissue samples}

Normal liver obtained at autopsy provided control tissue. Individuals were confirmed as having Gaucher's disease by the finding of Gaucher cells in an aspirate of bone marrow and by their profound deficiency of leukocyte, splenic or liver glucocerebrosidase activity. Table I describes the five Gaucher patients who were studied in the present report. Tissues were stored at $-70^{\circ} \mathrm{C}$ for 3 months to 2 years.

\section{Tissue extraction}

All procedures were carried out at $1-4^{\circ} \mathrm{C}$. Liver samples (approximately 50 mg) were homogenized with the aid of a Potter-Elvehjem homogenizer in 10 volumes of $10 \mathrm{mmol} / \mathrm{l}$ sodium phosphate, $\mathrm{pH} 6.0$, containing $10 \mathrm{mmol} / \mathrm{l}$ 2-mercaptoethanol and $0.02 \%(\mathrm{w} / \mathrm{v})$ sodium azide. Sodium azide is added as an anti-bacterial agent to all buffers stored at room temperature. The crude homogenate was used directly for all experiments.

\section{Enzyme assays}

The standard $\beta$-glucosidase assay (Table III) contained $10 \mathrm{mmol} / \mathrm{l} \mathrm{MUG \text {, }}$ $20 \mathrm{mmol} / \mathrm{l}$ sodium acetate, pII 5.5, and an appropriate amount of enzyme-protein (between $50-80 \mu \mathrm{g}$ ) in a final volume of $0.1 \mathrm{ml}$. All incubations were carried out for $1 \mathrm{~h}$ at $37^{\circ} \mathrm{C}$ with gentle shaking. The reaction was terminated and fluorescence determined as previously described [17]. Glucocerebrosidase activity in liver extracts was also assayed using the authentic substrate labeled in the stearoyl side chain (Table I). The assay mixture contained $79,100 \mathrm{cpm}$ of 
TABLE I

PATIENT DESCRIPTIONS

\begin{tabular}{|c|c|c|c|c|c|}
\hline Case No. & $\begin{array}{l}\text { Age } \\
(y \mathbf{r})\end{array}$ & Sex & Type of Gaucher's disease & $\begin{array}{l}\text { Glucocere- } \\
\text { brosidase } \\
\text { activity * } \\
\text { (units/mg) }\end{array}$ & Comments \\
\hline 1 & 71 & M & Adult, type 1 & $7.39[8.3] * * *$ & $\begin{array}{l}\text { Caucasian, Ashkenazi } \\
\text { Jewish, death due to } \\
\text { leukemia }\end{array}$ \\
\hline 2 & 1.3 & $\mathbf{F}$ & Infantile, type II & $0.05[<1]$ & Black ** \\
\hline 3 & 2.0 & $\mathbf{F}$ & Infantile, type II & $0.05[<1]$ & Black \\
\hline 4 & 11 & $\mathbf{F}$ & Juvenile, type III & $0.098[<1]$ & Caucasian \\
\hline 5 & fetus & unknown & Infantile, type II & $0.05[<1]$ & $\begin{array}{l}\text { Parents had another child } \\
\text { with Gaucher's disease }\end{array}$ \\
\hline
\end{tabular}

* Activity determined using labeled glucocerebroside as substrate, as described in "Materials and Methods"; controls, 40.4 units/mg ( \pm 10.1 ).

** Described elsewhere [20].

*** The number in brackets represents percent activity relative to normal liver glucocerebrosidase activity. Control liver was obtained from 8 individuals aged 8.75-72 years who died of Friedreich's ataxia; glioblastoma multiforme; hepatic failure due to alcoholism; atherosclerosis and pulmonary embolism; chronic lymphocy tic leukemia; multiple myeloma; emphysema; and pulmonary fibrosis and respiratory failure.

$\left[{ }^{14} \mathrm{C}\right]$ glucocerebroside, $20 \mathrm{mmol} / 1$ sodium acetate, $\mathrm{pH} 5.5,1.2 \%(\mathrm{w} / \mathrm{v})$ sodium taurocholate and an appropriate amount of enzyme protein (usually $0.3-0.5$ $\mathrm{mg}$ ), in a final volume of $0.1 \mathrm{ml}$. Incubations were carried out for $1 \mathrm{~h}$ at $37^{\circ} \mathrm{C}$ with gentle shaking. The product, $\left[{ }^{14} \mathrm{C}\right]$ ceramide, was separated from unreacted substrate using silicic acid (Unisil) chromatography and quantitated as previously described [18]. Preliminary experiments showed that there was no significant difference in the results if heat-killed blanks were used instead of blanks terminated at zero hour. Consequently, zero-time blanks were used in all experiments.

One unit of enzyme activity is defined as that amount of enzyme which cleaves $1 \mathrm{nmol}$ of glucose from the appropriate substrate, per hour, at $37^{\circ} \mathrm{C}$.

\section{Protein determination}

Protein was determined by the method of Lowry et al. [19] using bovine serum albumin as standard.

\section{Results}

Distribution of $\beta$-glucosidase and $\beta$-glucocerebrosidase activity in normal tissue

Table II summarizes the distribution of $\beta$-glucosidase and glucocerebrosidase activity in the $100000 \times g$ supernatant and particulate fractions, respectively, derived from homogenates of normal human tissues. Liver is the only tissue in which the broad specificily $\beta$-glucosidase is the predominant enzyme, constituting $77 \%$ of the total $\beta$-glucosidase activity measured by the standard fluorometric assay. In some patients with Gaucher's disease, the deficiency of gluco- 
TABLE II

DISTRIBUTION OF THE BROAD-SPECIFICITY $\beta$-GLUCOSIDASE AND GLUCOCEREBROSIDASE IN CONTROI, HUMAN LIVER

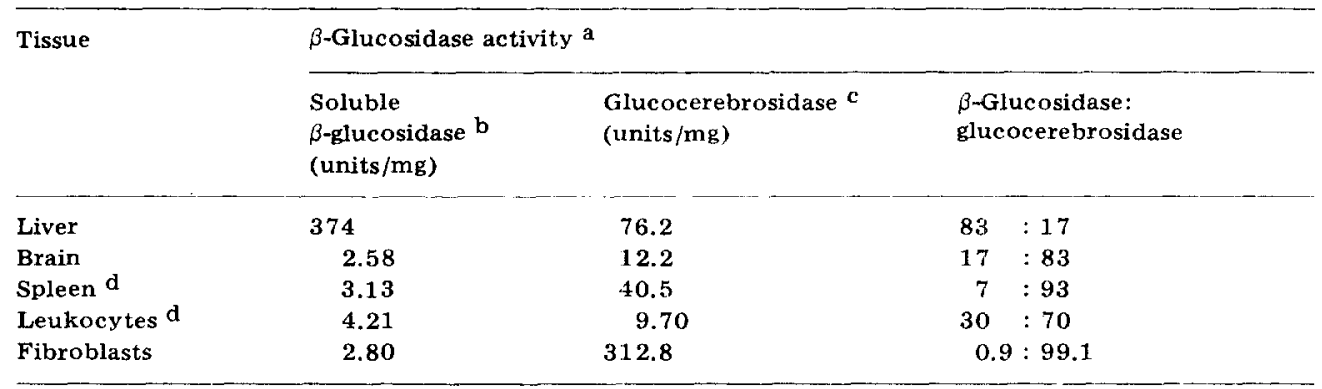

a $\beta$-Glucosidase activity was determined as described under "Methods."

b Soluble $\beta$-glucosidase represents activity measured in the high speed $(100000 \times g)$ supernatant'fraction using the standard $\beta$-glucosidase assay described under "Methods".

c Glucocerebrosidase activity represents activity measured in the particulate fraction.

d Keported elsewhere [ 2 ].

cerebrosidase in liver is associated with an increase in the level of the broadspecificity $\beta$-glucosidase thereby making liver an unsatisfactory source of enzyme for the common fluorometric diagnostic assays. Recognizing that liver biopsy material is occasionally used for diagnostic purposes when Gaucher's disease is suspected, we tested various compounds which might act as differential inhibitors of $\beta$-glucosidase and glucocerebrosidase.

Effects of various inhibitors on $\beta$-glucosidase and $\beta$-glucocerebrosidase activity

Partially purified preparations of liver non-specific $\beta$-glucosidase and glucocerebrosidase were assayed in the presence of a variety of gluconamides, galactonamides, lactones and CBE (Table III). The results indicated that there were three classes of compounds: (1) compounds which did not inhibit either enzyme significantly, (2) those which were inhibitory but which did not distinguish between the two enzymes, and (3) one compound which significantly inhibited only one of the two enzymes. The following compounds constituted the first category: D-gluconamide, $N$-(6-aminohexyl)-D-gluconamide, D-glucose, D-galactonamide, D-galactonyl hydrazide, $N$-(2-aminoethyl)-D-galactonamide and 1,4-galactonolactone. D-gluconyl hydrazide, 1,5-gluconolactone, and hexane diamine inhibited both enzymes to different degrees, but the differences were not sufficient to allow us to extend the application of the fluorometric assay to liver. $10 \mathrm{mmol} / \mathrm{l} \mathrm{D}$-gluconyl hydrazide inhibited $22.5 \%$ of the glucocerebrosidase activity as compared to $47.1 \%$ of the $\beta$-glucosidase activity. 1,5-Gluconolactone $(10 \mathrm{mmol} / \mathrm{l})$ inhibited glucocerebrosidase $51.2 \%$ and $\beta$-glucosidase $93 \%$. The same concentration of hexane diamine inhibited glucocerebrosidase activity $44.5 \%$ and $\beta$-glucosidase $6.6 \%$. None of thesc compounds proved satisfactory in differentiating glucocerebrosidase and $\beta$-glucosidase activities in crude homogenates of liver. However, the results of inhibitor studies with CBE were particularly interesting and of potential practical value. When present at a concentration of $6.2 \mathrm{mmol} / 1$ in the standard $\beta$-glucosidase assay, CBE completely inhibited glucocerebrosidase activity but had virtually no 
TABLE III

COMPARISON OF THE EFFECTS OF VARIOUS COMPOUNDS ON GLUCOCEREBROSIDASE AND BROAD-SPECIFICITY $\beta$-GLUCOSIDASE FROM CONTROL HUMAN LIVER

\begin{tabular}{|c|c|c|c|}
\hline \multirow{2}{*}{$\begin{array}{l}\text { Compounds added to incubation } \\
\text { medium }\end{array}$} & \multirow{2}{*}{$\begin{array}{l}\text { Final } \\
\text { concentration }\end{array}$} & \multicolumn{2}{|c|}{$\beta$-Glucosidase activity a } \\
\hline & & $\begin{array}{l}\text { Glucocere- } \\
\text { brosidase b } \\
\text { (\% of control) }\end{array}$ & $\begin{array}{l}\text { Soluble } \\
\beta \text {-glucosidase } \mathrm{c} \\
(\% \text { of control) }\end{array}$ \\
\hline None & & 100 & 100 \\
\hline Sodium taurocholate & $1.2 \%(\mathrm{w} / \mathrm{v})$ & 862 & 16.4 \\
\hline D-Gluconamide & $10 \mathrm{mmol} / \mathrm{I}$ & 101 & 102 \\
\hline D-Gluconyl hydrazide & $10 \mathrm{mmol} / 1$ & 75.5 & 52.9 \\
\hline$N$-(6-Aminohexyl)-D-gluconamide & $10 \mathrm{mmol} / \mathrm{l}$ & 94.1 & 87.1 \\
\hline 1,5 -Gluc onolactone & $10 \mathrm{mmol} / \mathrm{l}$ & 48.8 & 7.0 \\
\hline D-Glucose & $10 \mathrm{mmol} /$ & 90.9 & 95.5 \\
\hline D-Galactonamide & $10 \mathrm{mmol} / 1$ & 95.1 & 92.6 \\
\hline D-Galactonyl hydrazide & $10 \mathrm{mmol} / 1$ & 91.8 & 91.0 \\
\hline N-(2-Aminoethyl)-D-galactonamide & $10 \mathrm{mmol} / \mathrm{l}$ & 87.9 & 93.4 \\
\hline 1,4-Galactonolactone & $10 \mathrm{mmol} / 1$ & 98.0 & 82.0 \\
\hline Hexane diamine & $10 \mathrm{mmol} / \mathrm{l}$ & 65.5 & 93.4 \\
\hline Conduritol- $\beta$-epoxide & $6.2 \mathrm{mmol} / 1$ & 0.2 & 100 \\
\hline
\end{tabular}

a The standard $\beta$-glucosidase assay contained: $10 \mathrm{mmol} / 1 \mathrm{MUG}$ and $20 \mathrm{mmol} / 1$ sodium acetate, $\mathrm{pH} 5.5$.

b Glucocerebrosidase was partially purified from the particulate fraction ( $100000 \times \mathrm{g}, 1 \mathrm{~h}$ ) from control human liver by column chromatography on CM-cellulose and DEAE-cellulose as described elsewhere [16]. The specific activity of the glucocerebrosidase preparation was 18.9 units/mg when assayed using the standard $\beta$-glucosidase assay in the absence of sodium taurocholate. The enzyme preparation was free of non-specific $\beta$-glucosidase activity.

c Soluble broad-specificity $\beta$-glucosidase was purified 50 -fold by chromatography on QAE-Sephadex and hydroxylapatite as described elsewhere [3] from the high-speed supernatant fraction (100 $000 \times \mathrm{g}, 1 \mathrm{~h})$ of human liver to a specific activity of 7500 units $/ \mathrm{mg}$. The preparation was free of glucocerebrosidase activity.

d Control activity represents the activity in the absence of additions to the standard $\beta$-glucosidase assay.

effect on non-specific $\beta$-glucosidase activity. Even when glucocerebrosidase was assayed in the MUG-fluorometric assay in the presence of $1.2 \%(\mathrm{w} / \mathrm{v})$ sodium taurocholate, CBE completely inhibited glucocerebrosidase activity. These results demonstrated that $\mathrm{CBE}$ might be useful in distinguishing between the two enzyme activities in a crude homogenate of liver. Additional experiments (data not shown) confirmed that the inclusion of $3-6 \mathrm{mmol} / \mathrm{l} \mathrm{CBE}$ in the standard fluorometric $\beta$-glucosidase assay supplemented with sodium taurocholate inhibited more than $95 \%$ of the glucocerebrosidase activity present in unfractionated crude extracts of control liver. This concentration range for $\mathrm{CBE}$ is similar to that used by Legler $[10,11]$ to inhibit the $\beta$-glucosidase of Aspergillus wentii.

Determinations of relative glucocerebrosidase activity in homogenates of liver from patients with Gaucher's disease

In a previous study [3] comparing various enzymatic diagnostic methods in which liver served as the source of enzyme, we demonstrated that the $\mathrm{pH}$ 5.5sodium taurocholate, fluorometric $\beta$-glucosidase assay was ineffective in identifying a case of adult Gaucher's disease. On the basis of that finding, we recommended against the use of a fluorometric assay for the diagnosis of 
Gaucher's disease when a liver biopsy provides the source of enzyme. Liver from that same patient (case 1) with the adult form of Gaucher's disease was included in the present study. As shown in Table IV, $\beta$-glucosidase determinations performed in the absence of CBE using the fluorogenic substrate in the $\mathrm{pH}$ 5.5-sodium taurocholate assay of Peters et al. [2] indicated that this patient's liver contained 16.8 units/mg of $\beta$-glucosidase activity. While this value is only $25-30 \%$ of the mean value for the control tissues, it is very close to the lower limit of the control range $(19.1$ units $/ \mathrm{mg})$. Nevertheless, the diagnosis of Gaucher's disease could be confirmed in each of the four neuropathic cases using the $\mathrm{pH}$ 5.5-sodium taurocholate assay first described by Peters et al. for leukocytes [2] and later for fibroblasts [3], even when the assay medium was not supplemented with CBE.

The results of incorporating $\mathrm{CBE}$ into the fluorometric $\beta$-glucosidase assay for Gaucher's disease are summarized in the right-hand column of Table IV under "relative glucocerebrosidase activity". Using this CBE-dependent fluorometric assay the homogenate of liver from the case of adult, non-neuropathic Gaucher's disease exhibited a level of residual glucocerebrosidase activity (5.0 units/mg, $9.6 \%$ of control mean) comparable to that obtained using the glucocerebrosidase assay that utilizes labeled glucocerebroside as the substrate (Table I, 11.7\% of control mean). With this modified, CBE-dependent fluorometric assay, the liver homogenate from case 1 exhibited a relative glucocerebrosidase content that was more than 3-fold less than the lower limit of the control range (15.3 units/mg). The incorporation of $\mathrm{CBE}$ into the $\mathrm{pH} 5.5$ sodium taurocholate $\beta$-glucosidase assay also yielded a procedure that resulted

TABLE IV

-GLUCOSIDASE ACTIVITY IN HOMOGENATES OF LIVER FROM CONTROLS AND PATIENTS WITH GAUCHER'S DISEASE, PERFORMED USING MUG AS THE SUBSTRATE IN THE PRESENCE AND ABSENCE OF CONDURITOL- $\beta$-EPOXIDE

\begin{tabular}{|c|c|c|c|}
\hline \multirow[t]{2}{*}{ Homogenates } & \multicolumn{2}{|c|}{$\beta$-Glucosidase activity ${ }^{a}$} & \multirow{2}{*}{$\begin{array}{l}\text { Relative glucocerebrosidase } \\
\text { activity b }\end{array}$} \\
\hline & $\begin{array}{l}\text { A } \\
\text { minus CBE }\end{array}$ & $\begin{array}{l}\text { B } \\
\text { plus CBE d } \\
\text { (units/mg) }\end{array}$ & \\
\hline \multicolumn{4}{|l|}{ Controls $(n=8)$} \\
\hline range & $19.1-105$ & $3.07-24.6$ & $15.3-95.6$ \\
\hline mean ( \pm S.D.) & $61.4( \pm 29.1)^{\mathrm{e}}$ & $9.3( \pm 7.29)$ & $52.1( \pm 27.5)$ \\
\hline \multicolumn{4}{|l|}{ Gaucher patients } \\
\hline case 1 & 16.8 & 11.8 & $5.00[9.6] \mathrm{c}$ \\
\hline case 2 & 7.06 & 5.38 & $1.68[3.2]$ \\
\hline case 3 & 3.01 & 1.51 & $1.50[2.9]$ \\
\hline case 4 & 3.47 & 1.32 & $2.15[4.1]$ \\
\hline case 5 & 3.76 & 2.40 & $1.36[2.6]$ \\
\hline
\end{tabular}

a The standard $\beta$-glucosidase assay was supplemented with $1.2 \%(\mathrm{w} / \mathrm{v})$ sodium taurocholate.

b Relative glucocerebrosidase activity is obtained by subtracting the values in column $B$ from those in column A.

c 'Ihe number in brackets indicates residual glucocerebrosidase activity expressed as percent of the mean control value.

d "Plus CBE" indicates that the final assay medium contained $6.2 \mathrm{mmol} / 1$ conduritol- $\beta$-epoxide.

e The number in parentheses indicates one standard deviation. 
in generally lower residual enzyme activities in the extracts of liver from all four of the neuropathic cases of Gaucher's disease. For example, according to the results obtained using the procedure of Peters et al. [17], case 2 had $12 \%$ as much hepatic $\beta$-glucosidase activity as the controls but when evaluated using the CBE-modified assay, her residual relative glucocerebrosidase activity was only $3.2 \%$ of control.

These results demonstrate that the CBE-modified fluorometric assay procedure effectively diagnoses Gaucher's disease using liver tissue as the source of enzyme.

\section{Discussion}

In the present report we have established conditions for assessing the relative glucocerebrosidase content of human liver using a fluorometric procedure, and we have demonstrated that this revised procedure can be used to confirm the diagnosis of Gaucher's disease in neuropathic and nonneuropathic cases as reliably as the assay that employs the natural substrate.

The results reported here indicate that liver can be used satisfactorily as the source of enzyme in a diagnostic fluorometric assay, thus overcoming the objections raised earlier by Ben-Yoseph and Nadler [9] and ourselves [3] concerning the reliability of the results obtained using any fluorometric $\beta$-glucosidase assay. This revised assay procedure provides a measure of glucocerebrosidase activity which is as reliable an indicator of the homozygous deficiency state as the assay that employs the authentic substrate. However, the fluorometric procedure is more amenable to routine use in the clinical laboratory because it is rapid, sensitive and does not require scintillation counting equipment. Since it is not uncommon for a clinical laboratory to receive liver biopsy material for the determination of glucocerebrosidase activity when Gaucher's disease is suspected, the need for a reliable and rapid fluorometric assay procedure is evident.

The CBE-dependent procedure described in this report may be useful in evaluating the effectiveness of glucocerebrosidase replacement therapy in Gaucher patients, since the uptake of the enzyme by the liver can be determined readily in biopsy samples.

As leukocytes from heterozygotes become available, it will be useful to evaluate the effectiveness of this revised $\beta$-glucosidase assay for carrier typing.

Conduritol- $\beta$-epoxide has been shown to be a $\beta$-glucosidase active-site reagent by other investigators $[10-15]$. Radin has shown that the two glucosidases in various mouse tissues show differential sensitivities to CBE [13]. We have demonstrated in this report that glucocerebrosidase and $\beta$-glucosidase from a human source are also affected differently by this inhibitor, thus adding one more property to the growing list of distinctions between these two enzymes. The soluble $\beta$-glucosidase is inhibited by sodium taurocholate and other bile salts, is inhibited by phosphatidic acid and other acidic phospholipids, has a broad substrate specificity as demonstrated using artificial substrates [2] and is unaffected by CBE. Conversely, human glucocerebrosidase is activated by sodium taurocholate as well as by phosphatidic acid and other phospholipids, acts on a very narrow range of substrates [2] and is profoundly inhibited by 
CBE. This latest distinction - the different sensitivities to CBE -- suggests that the active sites of these two enzymes are profoundly different. Therefore, if both enzymes are derived from a single parent gene product, post-translational modification must occur in the region of the active sites to produce two enzymes with different enzymatic-kinetic properties. If there is a precursorproduct relationship between these two $\beta$-glucosidases, CBE will be a valuable tool in future studies, since it has proved so effective in discriminating between these two enzymes.

\section{Acknowledgements}

This work was supported by grants to R.H.G. from the National Institutes of Health (AM 17564) and the National Foundation, March of Dimes, and by a grant to N.S.R. from the National Institutes of Health (NS 03192).

\section{References}

1 Drady, R.O. (1978) Glucosyl ceramide lipidosis: Gaucher's disease. In The Metabolic Basis of Inherited Disease (Stanbury, J.B., Wyngaarden, J.B. and Fredrickson, D.S., eds.), pp. 731-746, McGraw-Hill, New York

2 Peters, S.P., Coyle, P. and Glew, R.H. (1976) Differentiation of $\beta$-glucocerebrosidase from $\beta$-glucosidase in human tissues using sodium taurocholate. Arch. Biochem. Biophys. 175, 569-582

3 Chiao, Y.B., Glew, R.H., Diven, W.F. and Lee, R.E. (1980) Comparison of various $\beta$-glucosidase assays used to diagnose Gaucher's disease. Clin. Chim. Acta 105, 41-50

4 Buetler, E. and Kuhl, W. (1970) The diagnosis of the adult type of Gaucher's disease and its carrier state by demonstration of deficiency of $\beta$-glucosidase activity in peripheral blood leukocytes. J. Lab. Clin. Med. 76, 747-755

5 Ho, M.W., Seek, J., Schmidt, D., Veath, M.L., Johnson, W., Brady, R.O. and O'Brien, J.S. (1972) Adult Gaucher's disease: kindred studies and demonstration of a deficiency of acid $\beta$-glucocerebrosidase in cultured fibroblasts. Am. J. Genet. 24, 37-45

6 Pentchev, P.G., Brady, R.O., Hibbert, S.R., Gal, A.E. and Shapiro, D. (1973) Isolation and characterization of glucocerebrosidase from human placental tissue. J. Biol. Chem. 248, 5256-5261

7 Wenger, D.A., Clark, C., Sattler, M. and Wharton, C. (1978) Synthetic substrate $\beta$-glucosidase activity in leukocytes: A reproducible method for the identification of patient and carriers of Gaucher's disease. Clin. Genet. 13,145-153

8 Butterworth, J. and Broadhead, D.M. (1978) Acid $\beta$-glucosidase and the diagnosis of Ga. in liver and spleen. Clin. Chim. Acta 87, 433--440

9 Ben-Yoseph, Y. and Nadler, H.L. (1978) Pitfalls in the use of artificial substrates for the diagnosis of Gaucher's disease. J. Clin. Pathol. 31, 1091-1093

10 Legler, G. (1966) Untersuchungen zum Wixkungsmechanismus glykosidspaltender Enzyme, I. HoppeSeyler's Z. Physiol. Chem. 345, 197-214

11 Legler, G. (1968) Untersuchungen zum Wirkungsmechanismus glykosidspaltender Enzyme, III. HoppeScylcr's Z. Physiol. Chem. 349, $767 \quad 774$

12 Legler, G. (1970) Markierung des aktiven Zentrums der $\beta$-Glucosidasen A und B aus dem SüssmandelEmulsin mit $\left[{ }^{3} \mathrm{H}\right]$ 6-Brom-6-desoxy-condurit-B-epoxid. Hoppe-Seyler's Z. Physiol. Chem. 351, 25-31

13 Hara, A. and Radin, N.S. (1979) Destruction and resynthesis of mouse $\beta$-glucosidases. Biochim. Biophys. Acta $582,412-422$

14 Kanfer, J.N., Legler, G., Sullivan, J., Ragharvan, S.S. and Mumford, R.A. (1975) The Gaucher mouse. Biochem. Biophys. Res. Comm. 67, 85-90

15 Stephens, M.C., Bernatasky, A., Burachinsky, V., Legler, G. and Kanfer, J.N. (1978) The Gaucher mouse: Differential action of conduritol- $\beta$ epoxide and reversibility of its effects. J. Neurochem. 30 , 1023-1027

16 Erickson, J.S. and Radin, N.S. (1973) N-Hexyl-D-glucosyl sphingosine, an inhibitor of glucosyl ceramide $\beta$-glucosidase. J. Lipid Res. $14,133-137$

17 Peters, S.P., Lee, R.E. and Glew, R.H. (1975) A microassay for Gaucher's disease. Clin. Chim. Acta $60,391-396$

18 Miller, R.R., Peters, S.P., Kuhlenschmidt, M.S. and Glew, R.H. (1976) The use of ion-exchange resins in the application of protein samples to gel filtration columns. Anal. Biochem. 72, 45-48

19 Lowry, O.H., Rosebrough, N.J., Farr, A.L. and Randall, R.J. (1951) Protein measurement with the folin phenol reagent. J. Biol. Chem. 193, 265-275

20 Forster, J., Chambers, J.P., Peters, S.P., Lee, R.E. and Glew, R.H. (1978) Acute neuropathic Gaucher disease in a black infant. J. Pediatr. 93, 823-824 